\title{
Multicriteria Decision Analysis of Material Selection of High Energy Performance Residential Building
}

\author{
Monika Čuláková, Silvia Vičeková, Jana Katunská, Eva Krídlová Burdová \\ Technical University of Košice \\ Civil Engineering Faculty, Institute of Architectural and Environmental Engineering \\ e-mail: monika.culakova@tuke.sk, silvia.vilcekova@tuke.sk,jana.katunska@tuke.sk, \\ eva.kridlova.burdova@tuke.sk
}

\begin{abstract}
In world with limited amount of energy sources and with serious environmental pollution, interest in comparing the environmental embodied impacts of buildings using different structure systems and alternative building materials will be increased. This paper shows the significance of life cycle energy and carbon perspective and the material selection in reducing energy consumption and emissions production in the built environment. The study evaluates embodied environmental impacts of nearly zero energy residential structures. The environmental assessment uses framework of LCA within boundary: cradle to gate. Designed alternative scenarios of material compositions are also assessed in terms of energy effectiveness through selected thermal-physical parameters. This study uses multi-criteria decision analysis for making clearer selection between alternative scenarios. The results of MCDA show that alternative E from materials on nature plant base (wood, straw bales, massive wood panel) present possible way to sustainable perspective of nearly zero energy houses in Slovak republic.
\end{abstract}

Key words: material selection, energy effective building structures, embodied environmental impacts, multicriteria analysis

\section{Introduction}

The interaction between the environment and the society represent complex web of positive and negative feedback flows. By simplification of relationship between the environmental and the social systems, there are on one side, the flows of natural sources to the system, and on the other side, the flows of wastes, pollutants back to the environment. The extent and intensity of damage of the environment depends on its ability of regeneration and its assimilation capacity [1]. Pollutants for which the environment has little or no absorptive capacity create interdependency between the present and the future, the intensity of damage imposed on the future depends on current human activities. Each human activity is connected with energy demand which results in consumption of depletable resources and production of pollutants [1, 2]. The buildings are associated with large environmental impacts which come into play 
during its life cycle (from design and construction through operation and final demolition). Worldwide, the building sector uses great quantities of raw materials $(60 \%$ extracted from lithosphere), more than $40 \%$ of energy and emits about $36 \%$ of greenhouse gas emissions to the atmosphere [3,4]. Residential buildings are dominant elements in the building sector because they account for $75 \%$ of the total stock in Europe (single family houses $64 \%$, apartment blocks 36\%) [5]. These buildings are responsible for $63 \%$ of total energy consumption and $77 \%$ of total $\mathrm{CO}_{2}$ eq. emissions in the European building sector [6].

The identification of the buildings as one of the significant energy consumers led to the definition of some rules that are targeted at improvement in the energy performance of buildings towards to near zero energy buildings, through the reduction of energy consumption during the operation phase [7]. This energy consumption of building is considered as the energy that is used to maintain the occupants' comfort inside building. When taking whole building life cycle perspective into account, total energy includes occupational and embodied energy [8]. By decreasing energy demand for operation (e.g. improving of the building envelope, technical solutions, etc.) it is necessary to pay more attention to the energy consumption during material production, which represent the embodied energy and associated embodied emissions [9]. According to results from environmental studies of residential buildings located in 10 countries [10 - 22], have been found that the total average value of embodied energy is $4.23 \mathrm{GJ}$ per square meter of useful area and average value of embodied $\mathrm{CO}_{2} \mathrm{eq}$ is $388.569 \mathrm{~kg} \mathrm{CO}$ eq per square meter of useful area. For buildings constructed to conventional standards average embodied energy is $3.8 \mathrm{GJ} / \mathrm{m}^{2}$ and for low energy and passive energy buildings is $4.4 \mathrm{GJ} / \mathrm{m}^{2}$. The embodied energy of conventional buildings is equivalent to 4 - 10 years of operational energy, embodied energy of energy effective buildings is equivalent to $14-26$ years.

A growing body of knowledge from the comparative LCA studies of residential buildings with different load-bearing system $[11,16,23,24]$ suggests that timber alternatives can result in lower environmental load (mainly lower embodied energy and global warming potential) than equivalent designs made of steel, concrete and masonry during whole their life cycle.

\section{Case study of material solutions for building structures}

It is necessary to bridge the gap between growing occupants' comfort for living and reduction of environmental loads. The simplest and best chance for reduction of overall intensity of environmental loads is using suitable building materials in integrated design phase of building. This presented case study is focused on optimization of material selection of building structures in terms of energy effectiveness and environmental sustainability.

\subsection{Methods of assessment of material selection}

Environmental performance of material solutions is calculated by using methodology Life Cycle Assessment (LCA) within boundary: cradle to gate. LCA is standardized tool used to assess and report relevant environmental impacts of a product's life cycle. LCA framework is interpreted in international standards of series ISO 14040 - 44 [25] and consist of four interrelated steps: defining the goal and scope, creating the inventory, assessing the impact 
and finally interpreting the results. The analysis investigates the role of different building material compositions in terms of the embodied energy from non-renewable resources and the embodied equivalent emissions of $\mathrm{CO}_{2}$ and $\mathrm{SO}_{2}$ in near zero energy residential timber buildings. Embodied energy (EE) is the energy utilized during manufacturing phase of the building materials and represents the energy used to acquire raw materials (excavation) and manufacture. Similarly, embodied $\mathrm{CO}_{2}\left(\mathrm{ECO}_{2}\right.$, global warming potential GWP) and $\mathrm{SO}_{2}$ $\left(\mathrm{ESO}_{2}\right.$, acidification potential AP) represent the equivalent emissions within the LCA boundary - cradle to gate and in the case of plant materials take account of absorbing of $\mathrm{CO}_{2}$ during growth stage. The input data of these indicators are extracted from the Austrian LCA database - IBO [26]. In this study, it is also calculated environmental indicator $\triangle \mathrm{OI} 3$ which describes impact of building material in given structure layer and is calculated according to following equation (1) [27].

$$
\triangle O I 3=\frac{1}{3}\left[\frac{1}{10}\left(E E_{B M}\right)+\frac{1}{2}\left(E C O 2_{B M}\right)+\frac{100}{0,25}\left(E S O 2_{B M}\right)\right]
$$

where: $\mathrm{EE}_{\mathrm{BM}}$ - embodied energy of one structure layer - building material $\left[\mathrm{MJ} / \mathrm{m}^{2}\right], \mathrm{ECO} 2_{\mathrm{BM}}$ embodied emissions $\mathrm{CO}_{2}$ of one structure layer - building material $\left[\mathrm{kg} \mathrm{CO} \mathrm{CO}_{2} \mathrm{eq} / \mathrm{m}^{2}\right], \mathrm{ESO} 2_{\mathrm{BM}}$ embodied emissions $\mathrm{SO}_{2}$ of one structure layer - building material $\left[\mathrm{kg} \mathrm{SO} \mathrm{S}_{2} \mathrm{eq} / \mathrm{m}^{2}\right]$.

In this case study, the material solutions are designed for nearly zero energy houses in Slovakia, which are calculated for climatic conditions: $-15^{\circ} \mathrm{C}$ and $84 \%$ of humidity for exterior, $20^{\circ} \mathrm{C}$ and $50 \%$ of humidity for interior. For purpose of reduction of future operational energy demand and associated emission production, these alternative scenarios of building structures are compared through selected thermodynamic values such as $U$ - value ( $\mathrm{U}_{\mathrm{tb}}$, considering systematic thermal bridges), linear thermal transmittance $\left(\Psi_{\mathrm{e}}\right)$, surface thermal capacity $(\mathrm{C})$, phase shift of thermal oscillation $(\psi)$, relaxation time $(\tau)$ and minimal inner surface temperature $\left(\theta_{\text {si }}\right)$. The most of values are calculated by using software Svoboda Area 2009 and according to STN 730540. The mathematical calculation of the relaxation time is explained by following equation (2) and depends on the order of material layers. It assigns the ability of structure to stabilize the inertial temperature during stationary cooling (after turning the heating off) [28].

$$
\tau=\sum_{i=1}^{n}\left(\frac{d_{i^{2}}}{2 \mathrm{a}_{i}}+\frac{\lambda_{i} d_{i}}{a_{i}} \sum_{j=i+1}^{n} \frac{d_{j}}{\lambda_{j}}\right)
$$

where: $d$ - thickness $[\mathrm{m}], \lambda$ - coefficient of thermal conductivity $[\mathrm{W} /(\mathrm{m} . \mathrm{K})]$, a - temperature coefficient of conductivity $\left[\mathrm{m}^{2} / \mathrm{s}\right]$.

By help of assessing many (often conflicting) criteria we can select the optimal alternative for a given building design. The results of criteria for particular alternative scenarios are calculated by using multicriteria decision analysis (MCDA). MCDA is now widely accepted and popular as a non-monetary assessment method to aid decision-making when dealing with environmental issues in building projects [29]. The process of the multi-criteria analysis helps to bridge over several fields of expertise simultaneously and brings the possibility of weighting the different criteria in respect of a specific design and building context. Weights of evaluated criteria are calculated by means of Saaty's method, considering the relative level of significance and size of differences in values of criteria for particular alternatives [29, 30]. All 
investigated structures meet requirements for high energy performance residential buildings in terms of U-value and surface temperature therefore these criteria weren't taken into account for total calculation of MCDA. The resultant weights are $17.98 \%$ for $\mathrm{EE}$ and $\mathrm{ECO}_{2} ; 8.99 \%$ for $\mathrm{ESO}_{2} ; 3.27 \%$ for surface weight; $25.89 \%$ for phase shift of thermal oscillation and relaxation time. The total score of MCDA is calculated by using assessment methods: method weighted sum approach (WSA), ideal points analysis (IPA), technique for order preference by similarity to ideal solution (TOPSIS) and concordance discordance analysis (CDA). The best resultant score of WSA and TOPSIS is the number nearest to 1.0, of IPA is number nearest to 0.0 , and of CDA is the lowest number.

\subsection{Description of evaluated exterior walls}

This study presents evaluated exterior walls with different timber load-bearing system and which consist especially from materials on plant base. The wall structures are designed without possible to condensate of vapour in material compositions for determined climatic condition.

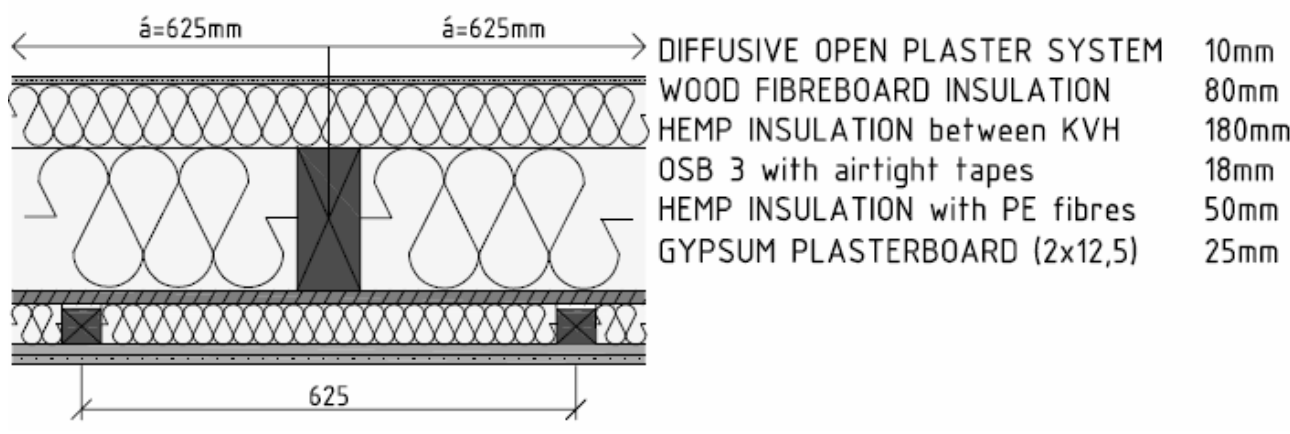

Figure 1: Composition of exterior wall A

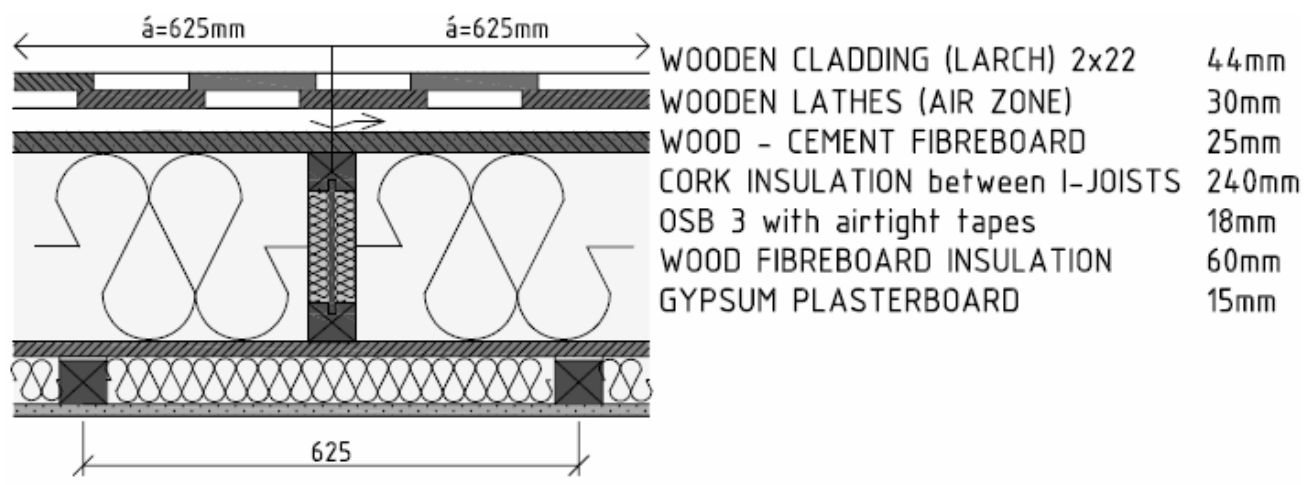

Figure 2: Composition of exterior wall B 


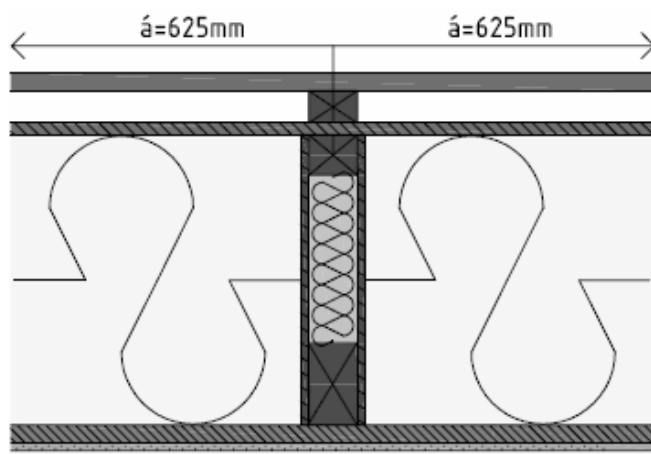

WOODEN CLADDING (LARCH) $22 \mathrm{~mm}$ WOODEN LATHES (AIR ZONE) $\quad 40 \mathrm{~mm}$ DIFFUSIVE WOOD FIBREBOARD DHF $15 \mathrm{~mm}$ CELLULOSE INSULATION between BOX BEAMS $360 \mathrm{~mm}$ OSB 3 with airtight tapes $22 \mathrm{~mm}$ LIME PLASTER

$10 \mathrm{~mm}$

Figure 3: Composition of exterior wall C

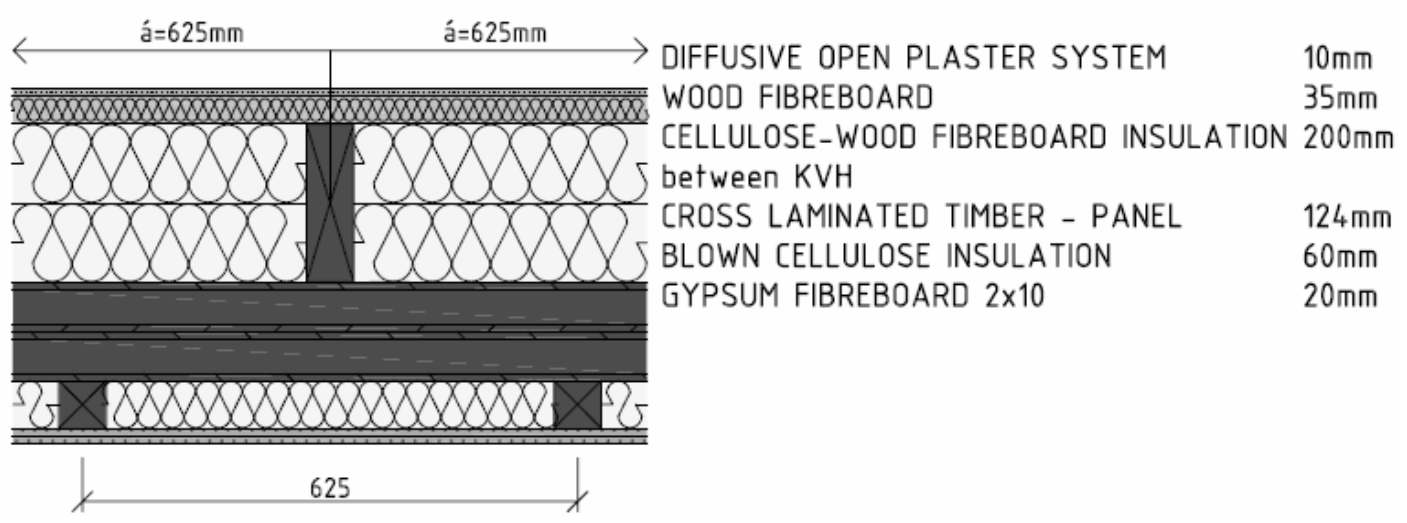

Figure 4: Composition of exterior wall D

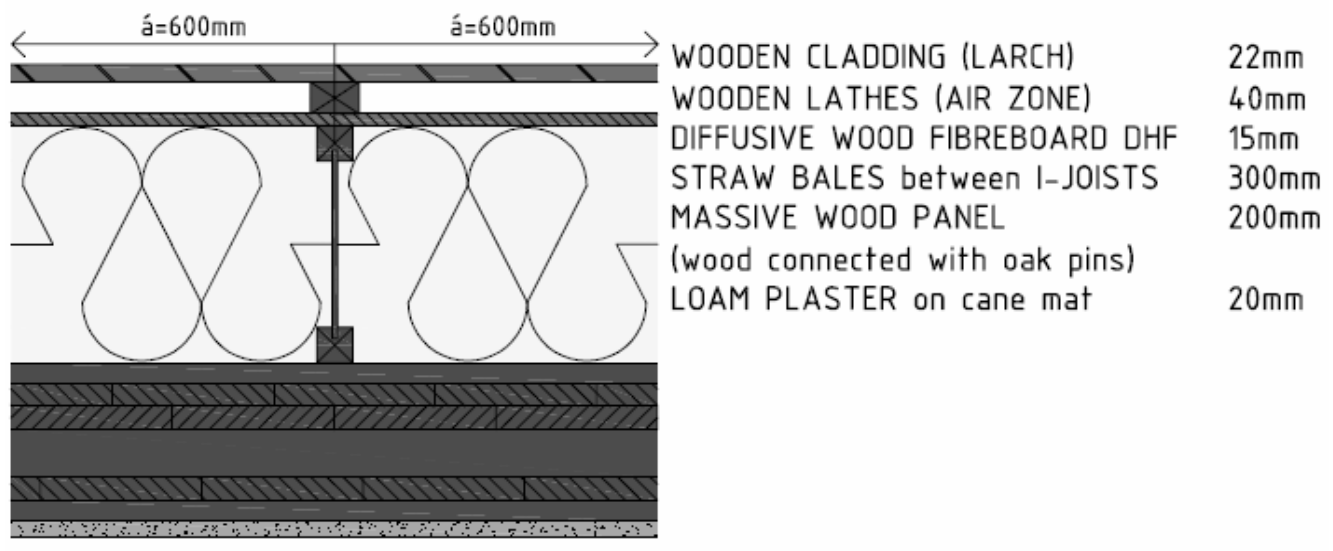

Figure 5: Composition of exterior wall E 


\subsection{Environmental assessment of material selection}

The following Fig. 6 illustrates impact particular main material groups (surface materials, thermal insulations, load-bearing system and others). Although the thermal insulations represent the highest share on total used material volume (more than 50\%), their share on environmental indicators isn't the highest. The thermal insulations only in alternative A participate more than $50 \%$ on embodied energy and embodied emissions of $\mathrm{SO}_{2}$. The insulation in alternative $\mathrm{E}$ has the lowest impact on total embodied energy; participate by only about $1.51 \%$. Furthermore, this insulation contributes for elimination of embodied emissions of $\mathrm{CO}_{2}$ by $23.43 \%$. The whole load bearing of structure alternatives represent $6.03 \%-$ $35.63 \%$ from total material volume. The timber systems of alternative D, E have high volume and represent the highest share of total embodied energy, embodied emission of $\mathrm{SO}_{2} \mathrm{eq}$ and reduction of embodied $\mathrm{CO}_{2}$ emissions. The environmental impact of each applied building material in structure alternatives $\mathrm{A}-\mathrm{E}$ is presented in Fig. $7-11$.

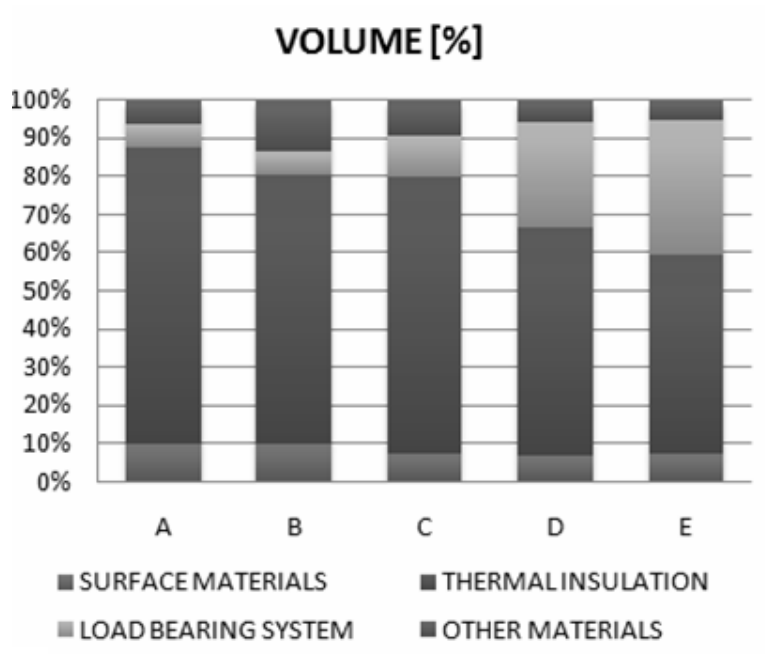

EMBODIED EMISSIONS ECO ${ }_{2}[\%]$

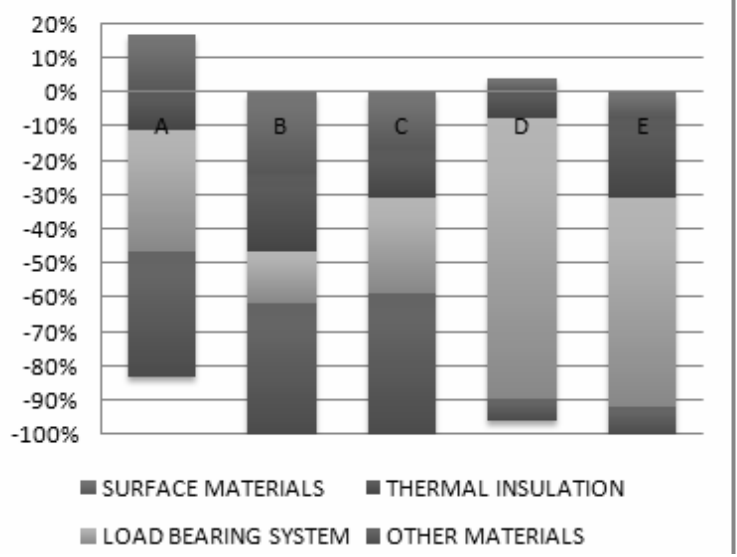

EMBODIED ENERGY EE [\%]

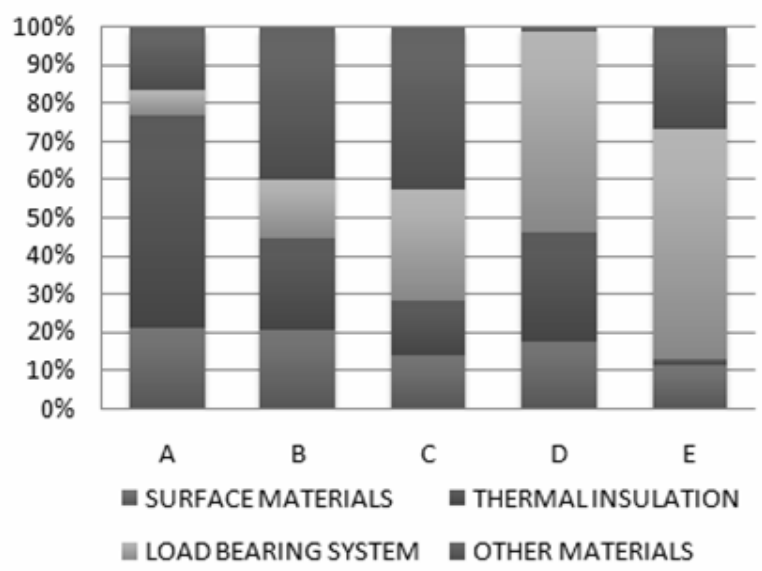

EMBODIED EMISSIONS ESO ${ }_{2}[\%]$

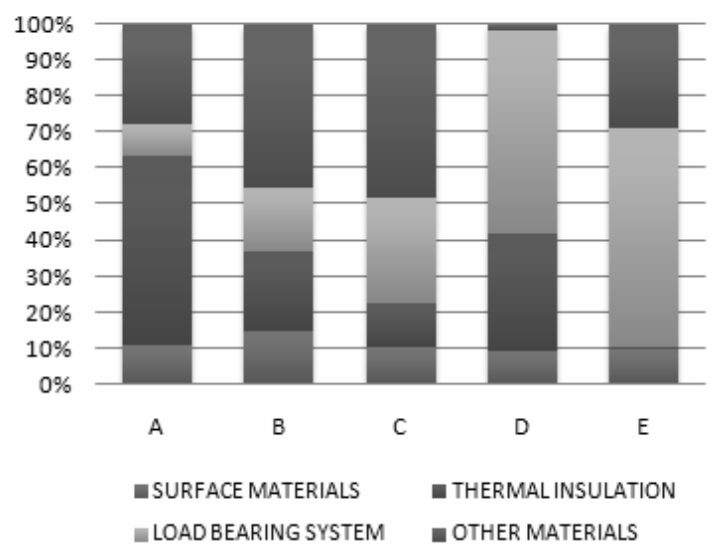

Figure 6: Environmental impact of particular material groups used in external walls A - E. 


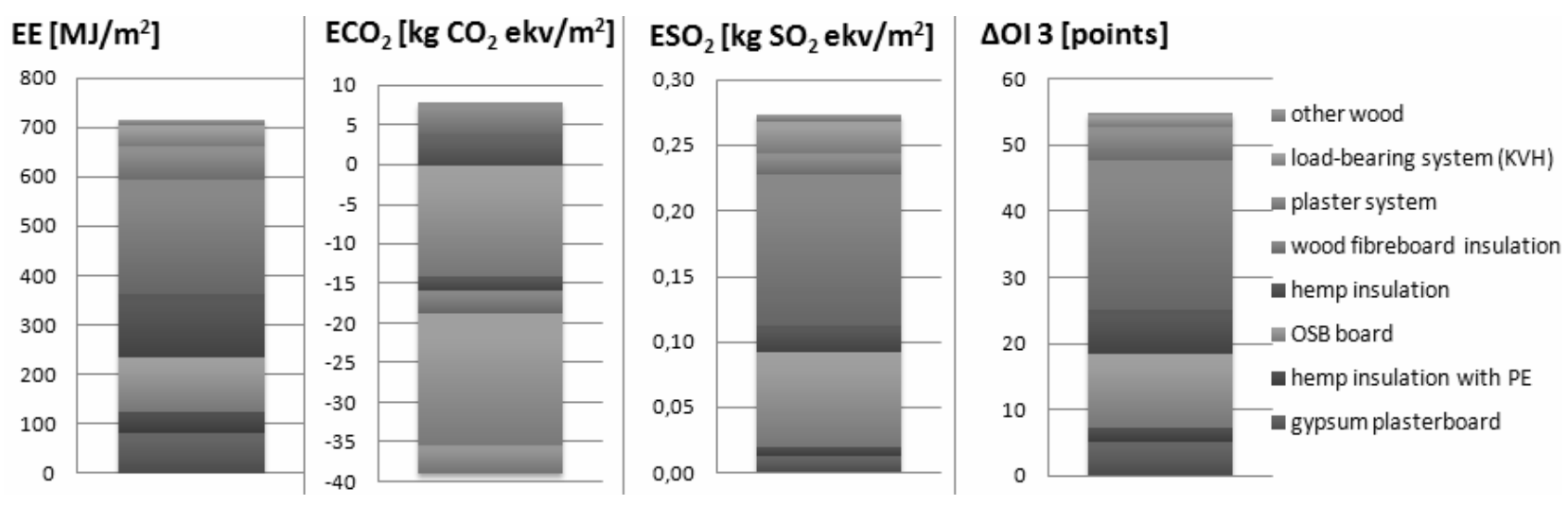

Figure 7: Environmental indicators of materials in external wall A

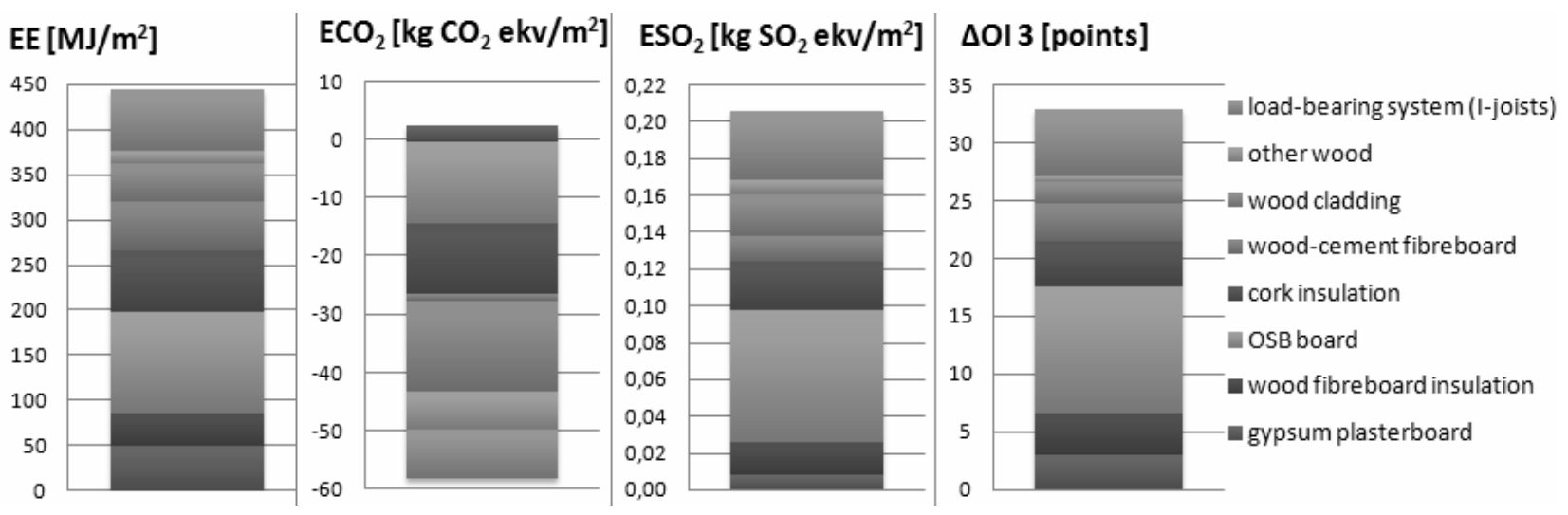

Figure 8: Environmental indicators of materials in external wall B

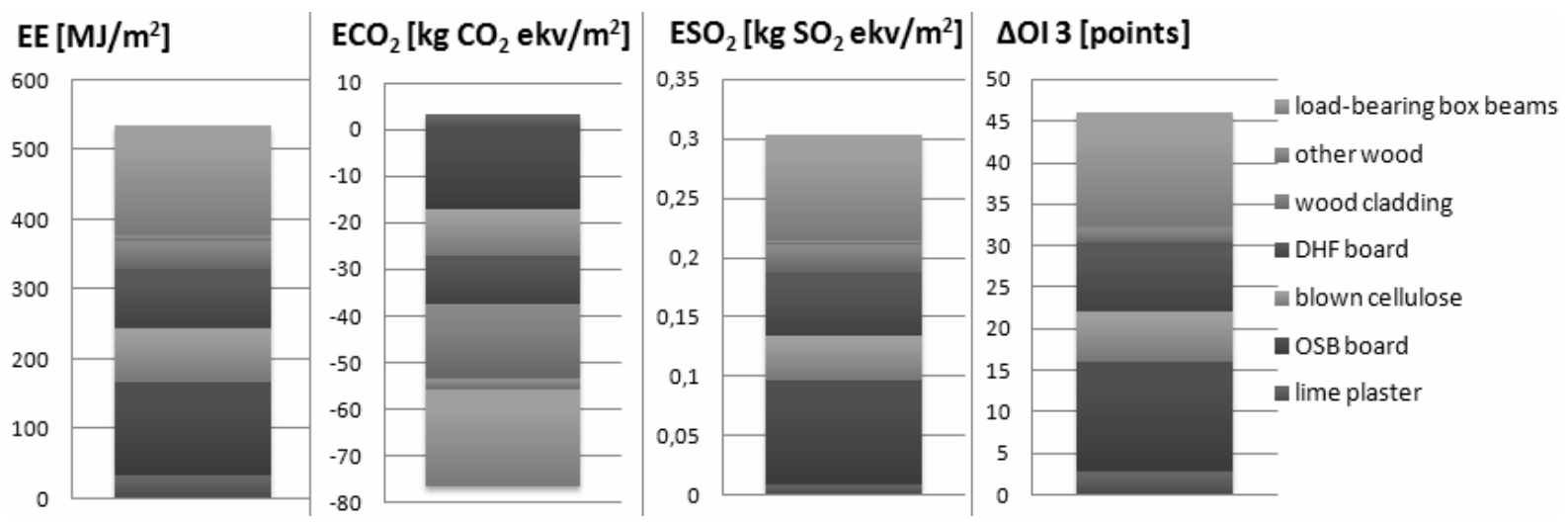

Figure 9: Environmental indicators of materials in external wall $\mathrm{C}$ 


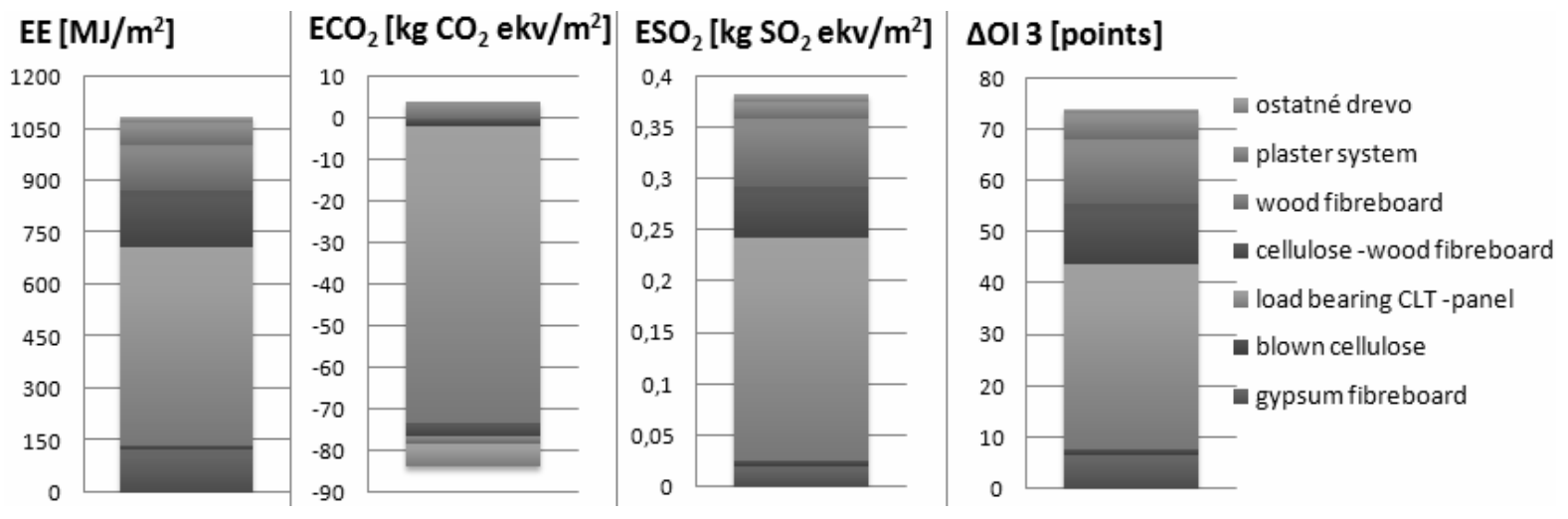

Figure 10: Environmental indicators of materials in external wall D

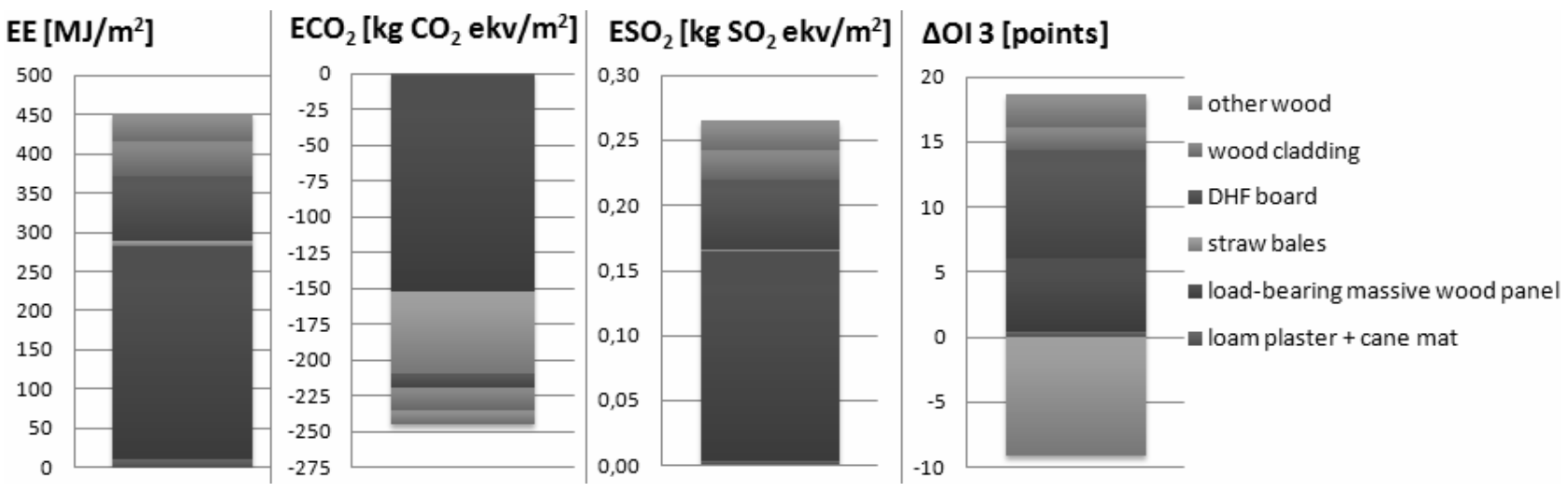

Figure 11: Environmental indicators of materials in external wall $\mathrm{E}$

The Fig. 7 - 11 demonstrate environmental balance of particular applied building materials in external wall alternatives A - E. As presented in Fig. 7, the thermal insulation in form wood fibreboard achieves the highest share of embodied energy, embodied emissions of $\mathrm{SO}_{2} \mathrm{eq}$ and value of environmental indicator $\Delta \mathrm{OI} 3$. In this alternative $\mathrm{A}$, the load bearing (wood $\mathrm{KVH}$ profiles) and OSB board contribute for reduction emissions $\mathrm{CO}_{2}$, by $32 \%$ and $29 \%$. As presented in Fig. 8, OSB board has the most negative impact on embodied energy, $\mathrm{SO}_{2} \mathrm{eq}$. emissions and environmental indicator $\Delta \mathrm{OI} 3$ in compared with other used materials in alternative wall B. In alternative C (Fig. 9), load bearing system in form box beams filled wood fibreboard insulation has significant impact on all presented environmental indicators. Although the blown cellulose represent more than $70 \%$ of total material volume in alternative $\mathrm{C}$ but it participates by only $14.47 \%$ on embodied energy, $12.34 \%$ on embodied $\mathrm{SO}_{2} \mathrm{eq}$ emissions and achieves 6 points of environmental indicator $\Delta \mathrm{OI} 3$. As presented in Fig. 10, the load bearing in form cross laminated wood panel achieves the highest share of embodied energy $(52.60 \%), \mathrm{SO}_{2}$ eq. emissions $(56.39 \%)$ and reduction embodied $\mathrm{CO}_{2}$ eq. emissions ($82.28 \%$ ). Application cross laminated wood panel is not very environmental effective by reason of high energy consumption during production phase and transport. In alternative $\mathrm{E}$ (Fig. 11), the insulation in form straw bales represents the high share in material volume 
$(51.73 \%)$ and has minimal share of embodied energy (1.51\%) and embodied emissions of $\mathrm{SO}_{2}$ eq. $(0.48 \%)$. This insulation contributes for elimination of $\mathrm{CO}_{2}$ emissions by $23.43 \%$. The load bearing system of alternative E (massive wood panel with connected with oak pins, without glue) represents the high share in material volume $(35.63 \%)$ and participates $60.31 \%$ on embodied energy, $60.88 \%$ on embodied $\mathrm{SO}_{2}$ emissions and on negative balance of embodied $\mathrm{CO}_{2}$ emissions, by $-60.79 \%$.

\subsection{Total results of evaluated external walls}

The total results of environmental assessment (Table 1) show that alternative B achieves the lowest value of embodied energy, embodied emissions of $\mathrm{SO}_{2} \mathrm{eq}$ and surface weight. The alternative of external wall $\mathrm{E}$ represents the most suitable solution in terms of embodied carbon and achieves low embodied energy.

Table 1: Environmental assessment results of exterior wall alternatives

\begin{tabular}{|c|c|c|c|c|}
\hline Alternative & $\begin{array}{c}\mathrm{EE} \\
{\left[\mathrm{MJ} / \mathrm{m}^{2}\right]}\end{array}$ & $\begin{array}{c}\mathrm{ECO}_{2} \\
{\left[\mathrm{~kg} \mathrm{CO} \mathrm{eq} / \mathrm{m}^{2}\right]}\end{array}$ & $\begin{array}{c}\mathrm{ESO}_{2} \\
{\left[\mathrm{~g} \mathrm{SO}_{2} \mathrm{eq} . / \mathrm{m}^{2}\right]}\end{array}$ & $\begin{array}{c}\text { Surface weight } \\
{\left[\mathrm{kg} / \mathrm{m}^{2}\right]}\end{array}$ \\
\hline $\mathrm{A}$ & 713.285 & -31.166 & 271.785 & 78.660 \\
$\mathrm{~B}$ & 444.028 & -56.031 & 205.731 & 76.367 \\
$\mathrm{C}$ & 533.854 & -73.361 & 303.567 & 87.215 \\
$\mathrm{D}$ & 1084.980 & -79.721 & 382.636 & 122.800 \\
$\mathrm{E}$ & 450.673 & -245.144 & 264.631 & 173.495 \\
\hline
\end{tabular}

The total results of thermodynamic values assessment (Table 2) point out that all evaluated alternatives comply U-value (considering systematic thermal bridges) for nearly zero energy houses $\left(\mathrm{U} \leq 0.15 \mathrm{~W} /\left(\mathrm{m}^{2} \mathrm{~K}\right)\right)$. The alternative $\mathrm{B}$ and $\mathrm{E}$ with insulation between wood I-joists represent the most effective solution in terms of linear thermal transmittance $(\Psi \mathrm{e})$. The alternatives $\mathrm{D}$ and $\mathrm{E}$ with wood panel achieve higher values of surface thermal capacity $(\mathrm{C})$, phase shift of temperature oscillation $(\psi)$, relaxation time $(\tau)$. The external wall $\mathrm{E}$ has positive impact on temperature stability of building and is the most suitable solution in terms of future energy consumption for heating and cooling.

Table 2: Thermal-physical assessment results of exterior wall alternatives

\begin{tabular}{|c|c|c|c|c|c|c|}
\hline Alternative & $\begin{array}{c}\mathrm{U}_{\mathrm{tb}} \\
{\left[\mathrm{W} /\left(\mathrm{m}^{2} \cdot \mathrm{K}\right)\right]}\end{array}$ & $\begin{array}{c}\Psi_{\mathrm{e}} \\
{[\mathrm{W} /(\mathrm{m} \cdot \mathrm{K})]}\end{array}$ & $\begin{array}{c}\mathrm{C} \\
{\left[\mathrm{kJ} /\left(\mathrm{K} \cdot \mathrm{m}^{2}\right)\right]}\end{array}$ & $\begin{array}{c}\psi \\
{[\mathrm{hrs}]}\end{array}$ & $\begin{array}{c}\tau \\
{[\mathrm{hrs}]}\end{array}$ & $\begin{array}{c}\theta_{\mathrm{si}} \\
{\left[{ }^{\circ} \mathrm{C}\right]}\end{array}$ \\
\hline $\mathrm{A}$ & 0.149 & 0.013 & 95.935 & 14.155 & 102.556 & 18.43 \\
$\mathrm{~B}$ & 0.138 & 0.009 & 82.039 & 13.761 & 97.395 & 18.29 \\
$\mathrm{C}$ & 0.125 & 0.012 & 82.620 & 13.759 & 137.372 & 18.17 \\
$\mathrm{D}$ & 0.142 & 0.015 & 227.870 & 21.463 & 350.317 & 18.24 \\
$\mathrm{E}$ & 0.125 & 0.004 & 319.170 & 30.183 & 608.050 & 18.91 \\
\hline
\end{tabular}

The material composition of exterior wall $\mathrm{E}$ achieves the best total score of assessment methods of multicriteria decision analysis, as seen in Table 3. The alternative A represents the lowest suitable solution from comprehensive perspective according to results of MCDA. 
Table 3: The resultant score of MCDA of exterior wall alternatives.

\begin{tabular}{|c|c|c|c|c|}
\hline Alternative & WSA & TOPSIS & IPA & CDA \\
\hline A & 0.2014 & 0.2151 & 0.7986 & 4.7268 \\
B & 0.3233 & 0.3266 & 0.6767 & 3.9493 \\
C & 0.2796 & 0.2967 & 0.7204 & 4.3312 \\
D & 0.3075 & 0.3426 & 0.6925 & 4.2561 \\
E & 0.9355 & 0.9111 & 0.0645 & 0.8282 \\
\hline
\end{tabular}

\subsection{Embodied energy versus U-value}

By assessed different material compositions of exterior walls which comply U-value of energy standard and near zero energy residential buildings is possible to compare impact of increasing insulation materials in structure compositions on embodied energy. As presented in Fig. 12, the material compositions are divided into three groups A-C. The group A involves 50 designed conventional material solutions for Slovak energy standard residential buildings according to STN 7305 40, the group B involves 40 conventional material compositions for Slovak near zero energy residential buildings and the group $\mathrm{C}$ involves analyzed material compositions A- E and another 55 alternative solutions for design of near zero energy residential buildings. The resultant values of embodied energy and U-values of each evaluated exterior wall indicate that alternatives of group $\mathrm{C}$ can achieve lower embodied energy than conventional energy standard solutions which consist of lower amount of building materials (mainly insulations). The most of alternatives from group $\mathrm{C}$ with higher embodied energy than value $900 \mathrm{MJ} / \mathrm{m}^{2}$ consist of cross laminated wood panel with wood fibreboard insulation. The suitable material selection, especially using nature materials, is possible design near zero energy residential building with minimal environmental impacts.

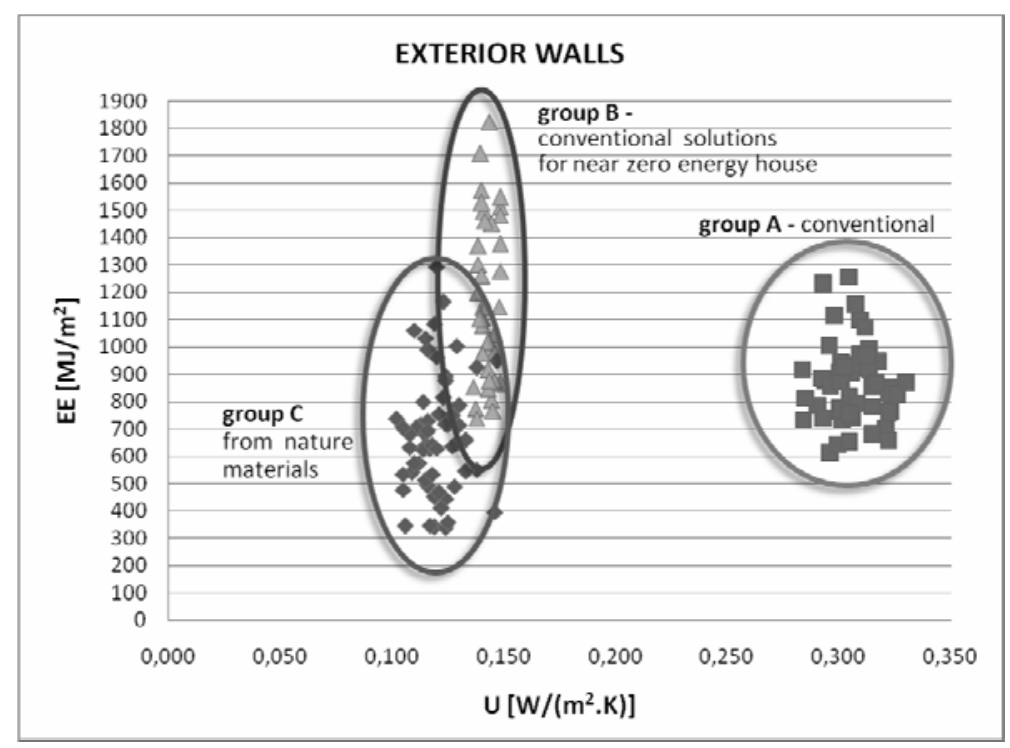

Figure 12: Embodied energy versus U-value of exterior walls 


\section{Conclusion}

This environmental analysis implements life cycle assessment within boundary-cradle to gate and indicate importance of choice of building materials. The suitable material compositions of structures, consisted of local available, renewable nature materials, can result in markedly lower environmental load during whole building life cycle than equivalent structures made of conventional materials. The alternative of exterior wall E (mainly from straw bales and massive wood panel) represent the most effective solution in terms of environmental and energy performance. This alternative achieves low embodied energy, the highest ability of reduction of carbon footprint and can assure minimal future energy consumption for heating and cooling. This solution demonstrates possible step towards to sustainable development.

\section{Acknowledgements}

This comparative analysis was financially supported by the Slovak Grants VEGA No. 1/0405/13 and KEGA No. 004TUKE-4/2011.

\section{References}

[1] Cordero, R.R., Roth, H P., \& Da Silva, L. (2005). Economic growth or environmental protection? Environmental Science and Policy. Volume 8, 392-398.

[2] Akadiri, O.P. (2011). ICT Development of a multi-criteria approach for the selection of sustainable materials for building projects. $\mathrm{PhD}$ Thesis (437).

[3] Li, D.Z. et al. (2013). A methodology for estimating the life-cycle carbon efficiency of a residential building. Building and Environment. Volume 59, 448-455.

[4] Wadel, G. (2009). Sustainability in industrialized architecture: Modular lightweight construction applied to housing. PhD Thesis. Polytechnic University of Catalonia-Department of Architectural Constructions.

[5] Economidou, M. et al. (2011). Europe's buildings under the microscope. Buildings Performance Institute Europe (132).

[6] Balaras, A. et al. (2007). European residential buildings and empirical assessment of the Hellenic building stock, energy consumption, emissions and potential energy savings. Building and Environment. Volume 42 (3), 1298-1314.

[7] Paleri, M., Lavagna, M. \& Campioli, A. (2012). Life cycle assessment of a zero energy residential building. In BSA, 23.-25. May 2012, Porto, Portugal, 641-650.

[8] Dimoudia, A. \& Tompa, C. (2008). Energy and environmental indicators related to construction of office buildings. Resources, Conservation and Recycling. Volume 53 (2), 86-95.

[9] Huberman, N. \& Pearlmutter, D. (2008). A life cycle energy analysis of building materials in the Negev desert. Energy and Buildings. Volume 40, 837-848.

[10] Nässén, J. et al. (2007). Direct and indirect energy use and carbon emissions in the production phase of buildings: An input-output analysis. Energy. Volume 32 (9), 1593-1602.

[11] Monahan, J. \& Powell, J.C.(2011). An embodied carbon and energy analysis of modern methods of construction in housing: A case study using a lifecycle assessment framework. Energy and Buildings. Volume 43 (1), 179-188. 
[12] Rossi, B., Marique, A.F. \& Reiter,S.(2012). Life-cycle assessment of residential buildings in three different European locations, case study. Building and Environment. Volume 51, 402-407.

[13] Gustavsson, L. \& Joelsson, A. (2010). Life cycle primary energy analysis of residential buildings. Energy and Buildings. Volume 42 (2), 210-220.

[14] Bribián, I.Z., Uséon, A.A. \& Scarpellini, S. (2009). Life cycle assessment in buildings: State-ofthe-art and simplified LCA methodology as a complement for building certification. Building and Environment. Volume 44, 2510-2520.

[15] Hammond, G. \& Jones, C. (2010). Embodied energy and carbon in construction materials. In Proceedings of the Institution of Civil Engineers: Energy. Volume 161, 87-98.

[16] Gustavsson, L., Joelsson, A. \& Sathre, R. (2010). Life cycle primary energy use and carbon emission of an eight-storey wood-framed apartment building. Energy and Buildings. Volume $42,230-242$.

[17] Stephan, R.H., Crawford, K. \& de Myttenaere, K. (2011).Towards a more holistic approach to reducing the energy demand of dwellings. Procedia Engineering. Volume 21, 1033-1041.

[18] Citherlet, S. \& Defaux, T. (2007) Energy and environmental comparison of three variants of a family house during its whole life span. Building and Environment. Volume 42 (2), 591-598.

[19] Asif, M., Muneer, T. \& Kelley, R. (2007). Life cycle assessment: A case study of a dwelling home in Scotland. Building and Environment. Volume 42 (3), 1391-1394.

[20] Hacker, J., et al. (2008). Embodied and operational carbon dioxide emissions from housing: a case study on the effects of thermal mass and climate change. Energy and Buildings. Volume 40 (3), 375-384.

[21] Thormark, C. (2006). The effect of material choice on the total energy need and recycling potential of a building. Building and Environment. Volume 41, 1019-1026.

[22] Vonka, M. (2006). Life cycle assessment of buildings. PhD thesis. ČVUT, Prague, http://www.vonka.wz.cz/publikace/Vonka dizertace teze.pdf

[23] Bribián, I.Z, Capilla, A.V. \& Usón, A.A. (2011). Life cycle assessment of building materials: Comparative analysis of energy and environmental impacts and evaluation of the eco-efficiency improvement potential. Building and Environment. Volume 46 (5), 1133-1140.

[24] Dodoo, A., Gustavsson, L. \& Sathre, R. (2009). Carbon implications of end-of-life management of building materials. Resources, Conservation and Recycling. Volume 53,276-286.

[25] De Benedetto L. \& Klemeš J. (2009). The Environmental Performance Strategy Map: an integrated LCA approach to support the strategic decision-making process. Journal of Cleaner Production. Volume 17, 900-906.

[26] Waltjen, T. (2009) Passivhaus-Bauteilkatalog, Ökologisch bewertete Konstruktionen. Wien, Austria, Springer (347).

[27] OI3-indicator: Leitfaden zur Berechnung von Ökokennzahlen für Gebäude. (2011). http://www.ibo.at/documents/OI3_Berechnungsleitfaden_V3.pdf

[28] Hejhálek, J. (2001). Thermal storage and inertia of wood houses. Architecture and Interior 2.

[29] Wang J.J., et al. (2009). Review on multi-criteria decision analysis aid in sustainable energy decision-making. Renewable and Sustainable Energy Reviews. Volume 13 (9), 2263-2278.

[30] Korviny, P. Theoretical basis of multi-criteria decision. (2009). PhD Thesis, Technical University of Ostrava, Czech Republic. 